\title{
Contributions to the Turkish Fauna of Spider Flies (Diptera: Brachycera: Acroceridae)
}

\author{
Derya ÇíFTÇI ${ }^{* 1}$, Abdullah HASBENLI ${ }^{2}$, Üzeyir ÇAĞLAR ${ }^{3}$, Şirin Bahar CAN ${ }^{2}$ \\ ORCID: 0000-0002-7670-4392; 0000-0002-2919-7594; 0000-0002-8401-015; 0000-0001-5787-5228 \\ ${ }^{1}$ Veysel Karani Mah. Siirt Üniversitesi Lojmanları 3E Blok No:8 Merkez, Siirt, Turkey \\ ${ }^{2}$ Gazi University, Science Faculty, Biology Department, 06500, Teknikokullar, Ankara, Turkey \\ ${ }^{3}$ Gazi University, Vocational High School of Health Services, Gölbaşı, Ankara, Turkey
}

\begin{abstract}
The Acroceridae family, an endoparasite in true spiders, is also referred to as spider flies. In this study, the list of Turkish Acrocerid species was updated with the newly recorded acrocerid species. The specimens in Zoological Museum of Gazi University collected from different regions of Turkey at different times (1997-2013) were evaluated. Acrocera laeta Gerstäcker, 1856 from Konya in central Anatolia and Ogcodes pallipes Latreille in Olivier, 1812 from Ardahan in northern east of Anatolia are recorded for the first time. Now Turkish Acrocerid fauna are ten species. The distribution map of the species are given.
\end{abstract}

Keywords: Acroceridae, Anatolia, fauna, new records

Türkiye örümcek sinekleri faunasına katkılar (Diptera: Brachycera: Acroceridae)

\section{Özet}

Gerçek örümceklerde endoparazit olan Acroceridae familyası, örümcek sinekleri olarak da anılır. Bu çalışmada, Türk Acrocerid tür listesi yeni kayıtlarla birlikte güncellenmiştir. Gazi Üniversitesi Zooloji Müzesi’nde bulunan Türkiye'nin farklı bölgelerinden farklı zamanlarda (1997-2013) toplanan örnekler değerlendirilmiştir. Acrocera laeta Gerstäcker, 1856 Orta Anadolu'da Konya'dan ve Ogcodes pallipes Latreille in Olivier, 1812 Kuzeydoğu Anadolu'da Ardahan'dan ilk defa kaydedilmiştir. Günümüz Türk Acrocerid faunası on türdür. Türlerin dağılış haritaları verilmiştir.

Anahtar kelimeler: Acroceridae, Anadolu, fauna, yeni kayitlar

\section{Introduction}

Acroceridae (Diptera: Brachycera) family known as spider flies, small-headed flies or swollen-bodied flies have a small head and a humbled thorax. There is a great variety in size and colour among the taxa. Their mouth parts are well developed, partially developed or absent. Those with well-developed mouth parts have an elongated proboscis. In this way, they feed on the nectar of flowers. Some acrocerid species are known as good pollinators in the ecosystem $[1,2]$.

Adult flies are short-lived, from one to six weeks. The flies are active only on warm sunny days [1]. The phenological information of some acrocerid species has been presented in previous studies. Accordingly, some species start to appear from May (such as Acrocera orbiculus and Ogcodes pallipes), while some species start to appear from June (such as Acrocera sanguinea and Ogcodes zonatus). They continue to appear until the end of August [10, 17]. Acrocerid larvae are endoparasitoids of true spiders (Araneae). Acrocerid females lay their eggs independently of the

\footnotetext{
${ }^{*}$ Corresponding author / Haberleşmeden sorumlu yazar: Tel.: +905366523645; Fax.: +905366523645; E-mail: dcanpolat@ gmail.com

(C) Copyright 2021 by Biological Diversity and Conservation Received: 10.01.2021; Published: 15.04.2021
} 
host but in the habitat where the spider lives. After the larva hatches from the egg, it awaits its host. After the larva finds its host, it adheres to the spider's body and usually settles between the spider's book lung lamellae [1, 2, 3].

Acroceridae is represented about 500 species in the world [4]. Although some acrocerid species are widely distributed, they are less known because they are rare in the field [1]. There are 34 species belonging to this family in Europe [5]. Studies on the Turkish Acroceridae family are few and insufficient. Until this study, seven species were known from the Turkish fauna $[6,7,8,9]$. In recent years, four species from Van province have been recorded. Three of them were new records $[7,8,9]$.

The aim of this study is to determine an update Acroceridae fauna of Turkey.

\section{Materials and methods}

The material discussed here is from the collection in Zoological Museum of Gazi University (ZMGU, Ankara, Turkey). The specimens were collected individually with a sweep net.

The species with detailed locality information in published papers and examined materials in this paper are shown on the distribution map. The species that recorded from Turkey but with no clear locality information (for example, as recorded in Asia Minor) are not shown on distribution map. The map was created in ArcGIS 10.1 program.

Identification work was carried out with the keys provided by Nartshuk [1] and Sack [10].

The species are given in alphabetical order. The Palaearctic distribution of species was obtained from Nartshuk [6] and Schlinger [11].

\section{Results}

23 acrocerid specimens (14 males, 9 females) in the Zoological Museum of Gazi University were evaluated. As a result of the examination, 6 species belonging to 3 genera were determined. The species are as follows; Acrocera (s.str.) laeta, A. (s.str.) orbiculus, Astomella hispaniae, Ogcodes pallipes, O. zonatus and Oligoneura murina. Among these species $A$. laeta and $O$. pallipes are new records for Turkish fauna. A total of 9 species are now known from Turkey (Table 1). The distribution map of the species is shown in Figure 1.

\section{Acrocera (s.str.) laeta Gerstäcker, 1856}

Material examined: Konya: Sariveliler, Gevne Valley, $36^{\circ} 35^{\prime} \mathrm{N}, 32^{\circ} 32^{\prime} \mathrm{E}, 1170 \mathrm{~m}, 01.07 .2001$, ㅇ, leg. A. Hasbenli

Remark: A. laeta was described from the male holotype collected on Sardinia (Italy) and also was recorded from USSR (SET, TC (Ge)) and Kazakhstan [6]. This species is new record for Turkish fauna. The species were collected from Gevne Valley located in the Middle Toros Mountains in the south of Turkey. In the Gevne valley, juniper, maquis, riparian and rocky plant communities, black pine (Pinus nigra), red pine (Pinus brutia) and Taurus fir (Abies cilicica ssp. isaurica) forests, high mountain meadows, steppe and agricultural areas have seen [12].

Acrocera (s.str.) orbiculus (Fabricius, 1787)

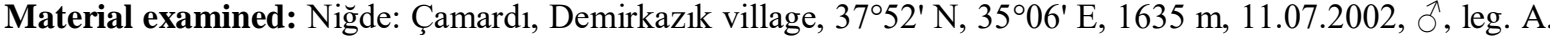
Hasbenli

Remarks: Acrocera orbiculus is a Holarctic (North America) species and one of the most frequently collected acrocerid in Palaearctic (Europe, USSR, Tajikistan, Kazakhstan, China, Algeria) [6, 13]. This species was recorded Van province for the first time from Turkey by Kemal and Koçak [7]. The second record is given in this paper.

\section{Acrocera (Acrocerina) sanguinea Meigen, 1804}

Remarks: The species is distributed in central and southern Europe [6]. It was recorded from Artos Mountain (Van) by Kemal and Koçak [8].

Astomella hispaniae Lamarck, 1816

Material examined: Antalya: Gündoğmuş, $36^{\circ} 48^{\prime} \mathrm{N}, 32^{\circ} 00^{\prime} \mathrm{E}, 980 \mathrm{~m}, 23.06 .1999$, ô, leg. A. Hasbenli;

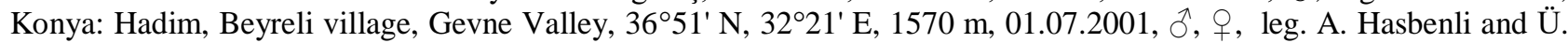
Çağlar.

Remarks: Astomella hispaniae is distributed in South Europe, Turkey, Syria and Algeria [6].

Ogcodes formosus Loew, 1873

Remarks: Loew [14] based the original description of Oncodes formosus a holotype from Shahrud, Iran. After that, this species was recorded from Artos Mountain (Van, Turkey) by Koçak and Kemal [7].

Ogcodes hirtus (Sack, 1936)

Remarks: The species was described from the female holotype collected on "Kurdistan ross." [10]. Schlinger stated the type locality of $O$. hirtus as "Kurdistan, Iran" and also gave the definition of the male [11]. Distribution information of the species was written as "south-eastern of Turkey" (? Turkey)" in the Catalogue of Palaearctic Diptera [6]. South-eastern region of Turkey has borders with the Kurdistan region in Iran. For this reason, we think that there may be confusion in the country names. Therefore, Turkey's record of this species is not clear. But we will consider the Ogcodes hirtus might be in Turkish fauna.

Ogcodes guttatus Costa, 1854 
Remarks: $O$. guttatus, the one nonendemic species, distributed the Palaearctic, Oriental and southern Ethiopian regions. One male specimen record, collected from İstanbul in 1925 leg. G. Edwards (deposited in BMNH), was published by Schlinger [11]. However, detailed locality information for the specimen was not given [11].

Ogcodes pallipes Latreille, 1811

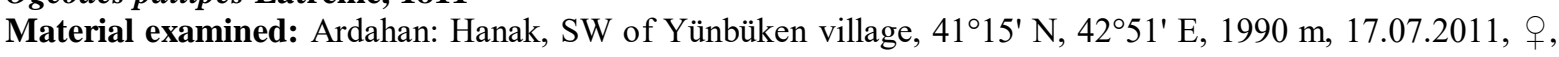
leg. A. Hasbenli and D. Çiftçi

Remarks: This species is new record for Turkish fauna. It is distributed in Europe and western Asia [6, 11]. EUNIS habitat type of the examined specimen's locality is "E4.4- Calcareous alpine and subalpine grassland" based on Davies et al. [15]. See Davies et al. [15] for detailed characteristics of this habitat.

Ogcodes zonatus Ercihson, 1840

Material examined: Adana: Pozant1, Hamidiye village, $37^{\circ} 31^{\prime} \mathrm{N}, 35^{\circ} 02^{\prime} \mathrm{E}, 1045 \mathrm{~m}, 21.07 .2002$, $\mathrm{o}^{\Uparrow}$, leg. A. Hasbenli; Eskişehir: Tepebaşı, NE of Takmak village, 3943' N, 30²0' E, 931m, 05.07.2013, ᄋ, leg. A. Hasbenli and D. Çiftçi; Kayseri: Yahyalı, around Derebağı waterfall, 1280 m, 25.06.1997,, , leg. A. Hasbenli.

Remarks: This species is widely distributed, reaching from Mongolia to Europe and south into North Africa, though it is as yet unknown from Scandinavia [11]. The first record from the Turkey was given by Kemal and Koçak [7] from Van province. Tragacanthic Astragalus species were dominant in the locality where was collected [7]. The specimens in this study were collected from steppe between sparse trees and shrubs.

Oligoneura murina (Loew, 1844)

Material examined: Adana: Tufanbeyli, Güzelim Village, $38^{\circ} 06^{\prime} \mathrm{N}, 36^{\circ} 10^{\prime} \mathrm{E}, 1490 \mathrm{~m}, 24.06 .2002$, ô, leg. A. Hasbenli; Aksaray: Güzelyurt, between Ihlara-Yenipınar, 38¹3' N, 34¹7' E, 1364 m, 14.06.2005, 今̂, leg. A. Hasbenli; Alanya: Aksu, 110 m, 06.05.1992, ô, leg. A. Hasbenli; Artvin: Yusufeli, Barhal Brook, 764 m, 18.07.2004, ㅇ, leg. A. Hasbenli; Erzincan: Tercan, N of Karacakışlak village, 3953' N, 40² $5^{\prime}$ E, 2082m, 19.07.2013, o, leg. A. Hasbenli and D. Çiftçi; Hatay: Dörtyol, Topaktaş Plateau, 3649' N, 36²19' E, 1114 m, 26.06.2004, ồ, +, leg. Ü.Çağlar; Kayseri:

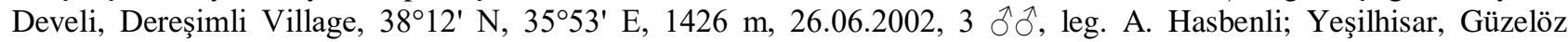
Village, 1260 m, 25.06.1997, ㅇ, leg. A. Hasbenli; Mersin: Mezitli, 7 km N of Findıkpınarı, 3657' N, $34^{\circ} 18^{\prime}$ E, 1927 m,

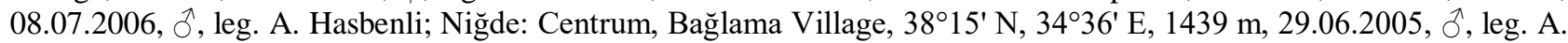

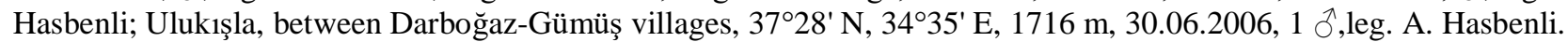

Remarks: The type locality was given by Loew in [16] as Kleinasien (Turkey) and Kos Island (Greece). In addition, the species was recorded from Greece, Armenia, Georgia and Iran [6].

\subsection{Checklist of Acroceridae}

A distributional checklist of Acroceridae (Diptera: Brachycera) of Turkey is presented as in Table 1.

Table 1. A distributional checklist of Acroceridae of Turkey

\begin{tabular}{|l|l|l|}
\hline \multicolumn{1}{|c|}{ Species } & \multicolumn{1}{|c|}{ Provinces and/or localities } & \multicolumn{1}{|c|}{ References } \\
\hline Acrocera laeta Gerstäcker, 1856 & Konya & This paper (new record) \\
\hline Acrocera orbiculus (Fabricius, 1787) & Niğde, Van & This paper, [7] \\
\hline Acrocera sanguinea Meigen, 1804 & Van (Artos Mountain) & {$[8]$} \\
\hline Astomella hispaniae Lamarck, 1816 & Konya, Antalya & This paper, [6] \\
\hline Ogcodes formosus Loew, 1873 & Van (Artos Mountain) & {$[7]$} \\
\hline Ogcodes guttatus Costa, 1854 & Istanbul (not shown on the map) & [6, 11] \\
\hline Ogcodes hirtus (Sack, 1936) & Not cited & $\begin{array}{l}\text { Narsthuk, 1998; Sack, 1936; } \\
\text { Schlinger, 1960 }\end{array}$ \\
\hline Ogcodes pallipes Latreille, 1811 & Ardahan & This paper (new record) \\
\hline Ogcodes zonatus Ercihson, 1840 & Adana, Eskişehir, Kayseri, Van & This paper, [6, 7] \\
\hline Oligoneura murina (Loew, 1844) & $\begin{array}{l}\text { Adana, Aksaray, Alanya, Artvin, } \\
\text { Erzincan, Hatay, Kayseri, Mersin, } \\
\text { Niğde }\end{array}$ & This paper [6, 16] \\
\hline
\end{tabular}




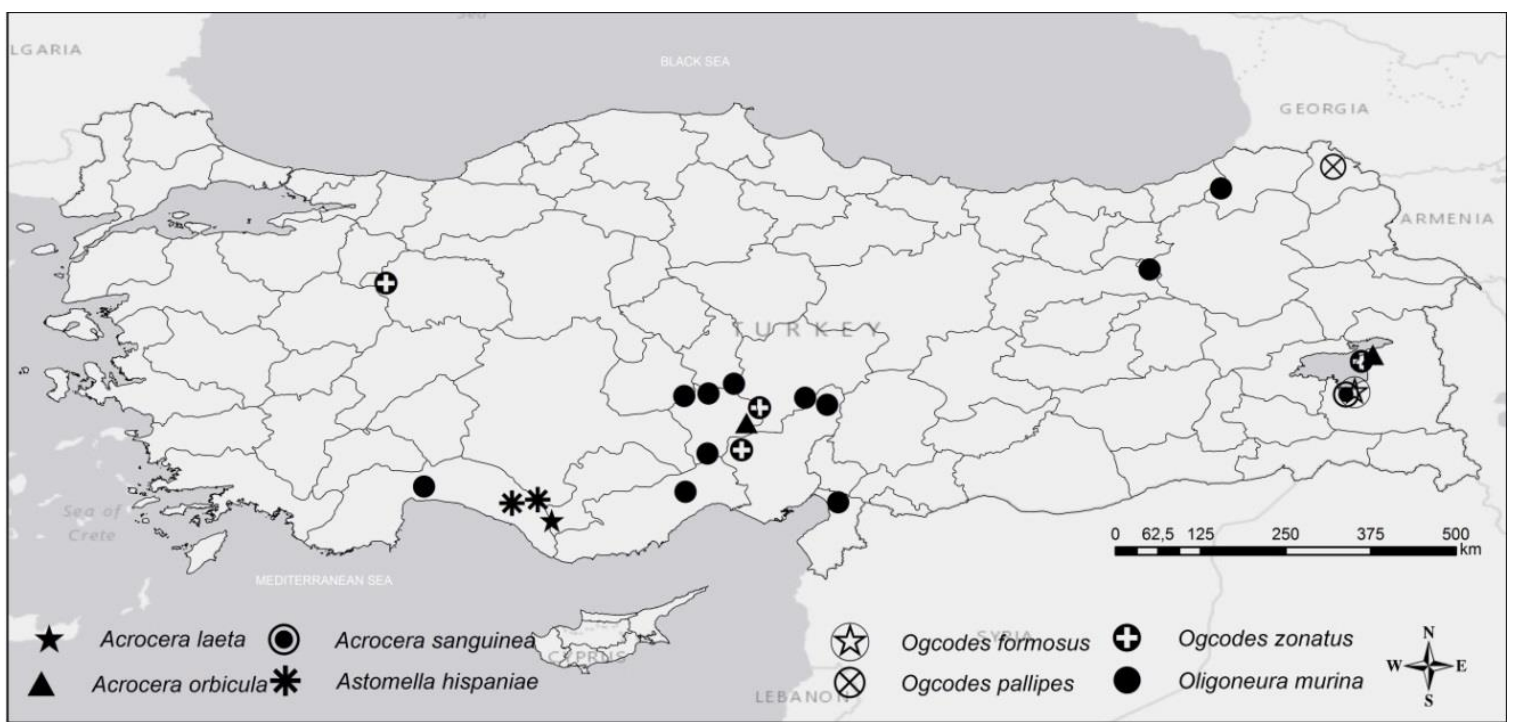

Figure 1. Distribution map of Turkish acrocerid species (Ogcodes guttatus not shown on the map).

\section{Conclusions and discussion}

As mentioned in the section above, the species of the acrocerid are active on hot sunny days [1]. In parallel to it, it is observed that the species recorded from Turkey are gathered in May, June, and July. Turkey is located between the subtropical zone and temperate zone. Different types of climate (Mediterranean, Continental, Marmara and Black Sea climate) are observed due to factors such as Turkey being surrounded by seas on three sides, the extension of mountains, and landforms. Due to these climates, summer months are generally hot and sunny in Turkey [18]. Therefore, it is considered that there will be more acrocerid species in the period between May and August compared to most parts of the country.

During their larval stages, acrocerids are internal parasites of true spiders. Naturally, females lay their eggs in habitats where spiders can live. While the subfamily Panopinae is Mygalomorphae spiders parasites, Acrocerinae is observed as a parasite in different Araneomorphae families. Palaearctic acrocerids were reared (from the following spider's families: Ctenizidae and Theraphosidae (Mygalomorphae) - Astomella species; Araneidae, Theridiidae, Lycosidae, Agelenidae, Oxyopidae, Anyphaeidae, Clubionidae, Gnaphosidae, Thomisidae and Salticidae (Araneomorphae) - Acrocera and Ogcodes species [1]. These spider families and species, in which acrocerids are parasites, are also recorded and distributed in Turkey $[19,20]$.

When the general situation of the Turkish Acroceridae fauna is compared with the European Acroceridae fauna, it is observed that it is not at a sufficient and satisfactory level. When Turkey's favorable climatic conditions and rich vegetation, and the diversity and richness of the spider fauna are considered, the Turkish acrocerid fauna is predicted to be richer.

\section{Acknowledgements}

The authors wishes thank Dr. C. Kehlmaier (Germany) for supplying some papers.

\section{References}

[1] Nartshuk, E. P. (1997). 2.32. Family Acroceridae. In: L. Papp \& B. Darvas (Eds.), Contributions to a Manual of Palaearctic Diptera 2: Nematocera and Lower Brachycera (pp. 469-485). Budapest: Science Herald.

[2] Winterton, S.L. \& Barraclough, D.A. (2017). Acroceridae. In: A.H. Kirk-Spriggs \& B.J. Sinclair (Eds.), Manual of Afrotropical Diptera. Volume 2. Nematocerous Diptera and Lower Brachycera. Suricata 5 (pp. 981-993). Pretoria: South African National Biodiversity Institute.

[3] Schlinger, E.I. (1987). The biology of Acroceridae (Diptera): True endoparasitoids of spiders. In: W. Nentwig (Eds.), Ecophysiology of Spiders (pp. 319-327). Berlin, Heidelberg, Newyork and Tokyo: Springer-Verlag. https://doi.org/10.1007/978-3-642-71552-5_24

[4] Nartshuk, E.P. \& Bagachanova, A.K. (2019). Small-Headed Flies (Diptera: Acroceridae) of Yakutia. Far Eastern Entomologist, 375: 7-10. https://doi.org/10.25221/fee.375.2

[5] Pape, T., Beuk, P., Pont, A., Shatalkin, A., Ozerov, A., Woźnica, A. ... \& de Jong, Y. (2015). Fauna Europaea: Diptera - Brachycera. Biodiversity Data Journal 3 (e4187): 1-31. https://doi.org/10.3897/BDJ.3.e4187

[6] Narsthuk, E.P. (1988). Family Acroceridae. In A. Soos \& L. Papp (Eds.), Catalogue of Palaearctic Diptera (pp. 186-196), Budapest: Akadémiai Kiado. 
[7] Kemal, M. \& Koçak, A.Ö. (2014). New Acroceridae for the fauna of Turkey (Diptera). Cesa News, 98, 1-2.

[8] Kemal, M. \& Koçak, A.Ö. (2016). Annotated list of the Pterygota fauna of Artos Mountain (Van Province, East Turkey). Cesa News, 125: 1-37.

[9] Koçak, A.Ö. \& Kemal, M. (2014). Revised and advanced list of the dipteran species of Turkey. Cesa News, 98, 14-105.

[10] Sack, P. (1936). 21. Cyrtidae (Acroceridae). In E. Lindner (Eds.), Die Fliegen der palaearktischen Region (pp. 140). Stuttgart: Schweitzerbartsche.

[11] Schlinger, E.I. (1960). A Revision of the Genus Ogcodes Latreille with Particular Reference to Species of the Western Hemisphere. Proceedings of the United States National Museum, 111 (3429): 227-336.

[12] Kartal, E. (2006). Gevne Vadisi ve Gökbel Yaylası AKD043. In G. Eken, M. Bozdoğan, S. İsfendiyaroğlu, D.T. Kılıç \& Y. Lise (Eds.), Türkiye'nin Önemli Doğa Alanları Cilt 2 (pp. 372-374). Ankara: Doğa Derneği.

[13] Kehlmaier, C. \& Almeida, J.M. (2014). New host records for European Acroceridae (Diptera), with discussion of species limits of Acrocera orbiculus (Fabricius) based on DNA-barcoding. Zootaxa, 3780 (1): 135-152. http://dx.doi.org/10.11646/zootaxa.3780.1.5

[14] Loew, H. (1873). Beschreibungen europäischer Dipteren. Systematische Beschreibung der bekannten europäschen zweiflügeligen Insecten von Johann Wilhelm Meigen. Halle, 3: 1-320.

[15] Davies, C. E., Moss, D. \& Hill, M. O. (2004). EUNIS Habitat Classification Revised 2004, Report to the European Topic Centre on Nature Protection and Biodiversity. France, Paris: European Environment Agency, 307 pp.

[16] Loew, H. (1844). Beschreibung einiger neuen Gattungen der europäischen Dipterenfauna. Stettin. Entomologische Zeitung, 5: 114-130, 154-173.

[17] Chvála, M. (1980). Acroceridae (Diptera) of Czechoslovakia. Acta Universita Carolinae-Biologica, 12: 253-267.

[18] Sensoy, S., Demircan, M. \& Ulupınar, Y. (2016). Climate of Turkey. Ankara: Turkish State Meteorological Service, $17 \mathrm{pp}$.

[19] Demir, H. \& Seyyar, O. (2017). Annotated checklist of the spiders of Turkey. Munis Entomology \& Zoology, 12 (2): 433-469.

[20] Özkütük, R.C., Elverici, M., Kunt, K.B. \& Kılıç, G. (2017). First faunistic record of Tegenaria vankeerorum Bolzern, Burckhardt \& Hänggi, 2013 (Araneae: Agelenidae) from Turkey with description of unknown female. Biological Diversity and Conservation, 10 (3): 184-189. 